\title{
Deference to the Administration in Judicial Review in Finland
}

\section{Mäenpää, Olli}

Springer

2019

Mäenpää , O 2019 , Deference to the Administration in Judicial Review in Finland . in G Zhu (ed.) , Deference to the Administration in Judicial Review : Comparative Perspectives . Ius Comparatum - Global Studies in Comparative Law , vol. 39 , Springer , Cham , pp. 181-201 . https://doi.org/10.1007/

http://hdl.handle.net/10138/321846

https://doi.org/10.1007/978-3-030-31539-9_9

unspecified

acceptedVersion

Downloaded from Helda, University of Helsinki institutional repository.

This is an electronic reprint of the original article.

This reprint may differ from the original in pagination and typographic detail.

Please cite the original version. 


\title{
Deference to the Administration in Judicial Review in Finland
}

\author{
Olli Mäenpää *
}

\begin{abstract}
$\underline{\text { Abstract }}$
The Finnish legal system shows only limited judicial deference to administrative discretion. Instead, more value is generally accorded to effective judicial protection and other related factors, such as adequate access to a court, guarantees of procedural fairness, the sufficiently broad scope of judicial review, effective remedies and a relatively active role for the administrative courts. In Finland, as in several other continental European jurisdictions with separate administrative courts, procedural law tends to attribute an active role to the courts. The courts exercise judicial power and play a central role in offering legal protection to individuals affected by administrative decision-making. Judicial review can constrain the exercise of executive power because of its emphasis on adherence to the law and legal principles. On the other hand, investigation of the advisability and expediency of an administrative decision falls outside the jurisdiction of the administrative courts. A further limit to judicial power is based on constitutional principles, more precisely on the separation of powers doctrine. According to that doctrine, the actual adoption of an administrative decision belongs exclusively to the sphere of executive power.
\end{abstract}

\section{Contents}

1. Introduction

1.1 General Background

1.2 Judicial Procedure

2. Special Characteristics

2.1 Procedural requirements

2.2 Definitions and characterizations

3. Judicial Deference

3.1 The Scope of Deference

3.2 Specific Types of Agency Action

4. Standards, approaches and grounds of review

4.1 Standard grounds of judicial review

4.2 Principles of administrative law as grounds of review

4.3 Constitutional grounds for review

4.4 The effectiveness of judicial review

5. Dimensions of Deference

5.1 The Role of Information and the Investigation Principle

5.2 Judicial Construction

5.3 Proportionality and other legal principles

*University of Helsinki, Finland. olli.maenpaa@ helsinki.fi. 
6. Activism or Restraint

7. Limits of Judicial Review

7.1 Policy Issues

7.2 Separation of Powers

7.3 Constitutional Review

7.4 Administrative Inaction

7.5 Local Self-government

8. Concluding Remarks

\section{Introduction}

\subsection{General Background}

\subsubsection{The Legal System and the Role of the Executive}

The Finnish legal system is based on the civil law tradition, and it belongs to the family of Nordic law. ${ }^{1}$ Its characteristics include a commitment to statutory law, respect for the Parliament and rule of law, an emphasis on practical legal thinking and a limited role of judicial precedents. $^{2}$

The welfare state, public administration and administrative agencies play a central role in all the Nordic countries. However, with respect to the relationship between the judiciary and the executive, a significant difference exists between the Eastern and Western Nordic states. Sweden and Finland have specific administrative courts hearing all appeals against administrative agencies. By contrast, Norway, Denmark and Iceland lack a system of administrative judiciary. In those countries, judicial protection is provided, to a certain extent, by ordinary courts, but in actual practice administrative disputes are mainly settled by special administrative tribunals or processed by administrative ombudsmen.

Legalism and strict adherence to law have traditionally played a central role in Finland. To be sure, formal legalism has been substituted by more goal-oriented and value-based objectives in the welfare state. Nevertheless, legalism continues to have significance in the exercise of administrative functions. With respect to public administration, the rule of law requires that the executive powers of any administrative authority must have an express basis in law, and the exercise of public power must be justified on grounds laid down by law. The principle applies especially when an administrative authority (e.g. a ministry, agency, municipality or public official) makes administrative decisions or performs other acts that directly affect the rights and obligations of a person. The rule of law is thus a necessary prerequisite in all exercise of administrative authority. In the provision of public services, legalism is somewhat more subdued, but a legal basis is still necessary for any social benefit or service.

\footnotetext{
${ }^{1}$ On the characteristics of Nordic Law, see Letto-Vanamo, Tamm (2019).

${ }^{2}$ For more detail, see Nuotio (2012).
} 
The Finnish Constitution (2000) stipulates that all public action must be authorised by law, the law must be strictly complied with in the exercise of any public activity and the executive must comply with the qualitative requirements of good, transparent and accountable administration; in addition, there must be access to judicial review for any administrative decision concerning one's rights or duties. According to the Constitution, it is the duty of the public authority (authorities) to ensure that fundamental and human rights are guaranteed and protected.

\subsubsection{Sources of Law}

The principal and most important sources of general administrative law are defined in the Constitution Act (2000). Its provisions identify the general constitutional limits of the executive as well as qualitative requirements for the activities of the administrative authorities. Of special significance for the role of the courts are the rule of law, the right to good administration, the right to a fair trial and effective judicial protection in administrative matters as well as the legal accountability of public officials.

The principal legislative basis of administrative activity is the Administrative Procedure Act (2003) and the Act on the Openness of Government Activities (1999). In turn, the framework for judicial procedure in the administrative courts is provided by the Act on Judicial Procedure in Administrative Courts (1996, AJPA). The AJPA contains general provisions on the right of appeal, the procedure to be followed in initiating the administrative appeal procedure and details of the review procedure in the administrative courts.

Access to judicial review in all administrative cases is defined as a constitutional right by Section 21(2) of the Constitution:

Everyone shall have the right to have his or her case heard appropriately and without undue delay by a court of justice or other authority competent under an Act of Parliament as well as the right to have a decision relating to his or her rights and duties reviewed by a court or other independent tribunal.

Openness of the proceedings as well as the right to be heard, to receive a decision with stated reasons and to appeal the decision as well as any other safeguards of fair trial and good government shall be secured by an Act of Parliament.

\subsubsection{The Judiciary}

The judiciary consists of two sectors. The administrative courts have jurisdiction in all administrative cases. The administrative courts are mainly concerned with administrative appeals concerning administrative decisions. Their jurisdiction also covers administrative litigation over administrative disputes between a public authority and private actors arising, for instance, from administrative contracts or claims for reimbursement.

The administrative court system functions on two levels. Supreme administrative jurisdiction is vested in the Supreme Administrative Court, which exercises the highest judicial power in administrative cases. At the regional level, the Administrative Courts are general first instance courts in administrative cases.

General courts have jurisdiction in civil and criminal cases. Due to the constitutionally guaranteed public accountability of administrative staff, civil and criminal procedures can also be used as avenues for seeking redress for administrative wrongs. However, since neither kind of procedure can result in a reversal or modification of the administrative decision, they have, at best, a secondary role in administrative cases and usually serve only as individual remedies complementing the judicial procedure in administrative courts. Disputes concerning private 
law contracts and actions also fall under the jurisdiction of general courts in cases where a public body is party to such a contract.

\subsection{Judicial Procedure}

The AJPA sets out a uniform judicial procedure for administrative courts. It also defines in more detail the right to appeal against an administrative decision and the reviewability of administrative acts. In addition to affirming or annulling the decision subject to review, an administrative court may also amend it, although not to the detriment of the appellant.

According to the AJPA, an administrative appeal may be directed against any act or measure of an administrative authority whereby a matter has been resolved or dismissed. The right to appeal may be exercised by any person to whom a decision is addressed or whose right, obligation or interest is directly affected by a decision. Judicial review focuses on the legality of administrative decisions. Consequently, an investigation into the advisability or expediency of those decisions is beyond the remit of the administrative courts.

The basis of judicial control is regulated, albeit in a fairly general manner, in European law, thus forming a general European standard on access to the judicial process and fair trial. According to Article 6(1) of the European Convention of Human Rights (ECHR) on the Right to a fair trial:

In the determination of his civil rights and obligations or of any criminal charge against him, everyone is entitled to a fair and public hearing within a reasonable time by an independent and impartial tribunal established by law.

Similarly, the Charter of Fundamental Rights of the European Union lays down the basic rules of judicial protection with respect to the application of EU law. Article 47, which defines the Right to an effective remedy and to a fair trial, states:

Everyone whose rights and freedoms guaranteed by the law of the Union are violated has the right to an effective remedy before a tribunal in compliance with the conditions laid down in this Article. Everyone is entitled to a fair and public hearing within a reasonable time by an independent and impartial tribunal previously established by law. Everyone shall have the possibility of being advised, defended and represented.

\section{Special Characteristics}

\subsection{Procedural requirements}

\subsubsection{Fair trial in administrative cases}

Guarantees of procedural fairness must also apply in judicial proceedings concerning administrative cases. In addition to the essential right of access to judicial review, these guarantees include the right to be heard and the right to procedurally equal status and to a public hearing.

The primary basis of judicial control of executive action is a court hearing. Both the private party and the public authority have a right to be heard. Both parties (or all the parties, as the case may be) must be presented an opportunity to comment on the demands of the other parties. They are also entitled to give their opinions on all the factual evidence that may affect the resolution of the matter. 
In order to exercise the right to be heard, the private party to an administrative judicial procedure enjoys considerable right of access to the case documents. In addition, the private appellant usually gains access to classified documents of potential relevance to the processing of the case.

According to the European Court of Human Rights, the adversarial nature of the procedure must be guaranteed. Thus, "each party must in principle have the opportunity not only to make known any evidence needed for his claims to succeed, but also to have knowledge of and comment on all evidence adduced or observations filed with a view to influencing the court's decision." 3 Such a confrontational procedure is necessary, since "the very purpose of adversarial procedure ... is to prevent the Court from being influenced by arguments which the parties have been unable to discuss". ${ }^{4}$

The minimum requirements for due process are clearly defined procedural rules, their regulation in law and their vigorous application in individual proceedings. All cases and parties must be treated equally and with equal fairness.

\subsubsection{Equality of the parties - Equality of arms}

A key measure of fairness in judicial procedure is equality. Only parties' equal treatment and equal procedural rights and obligations are capable of guaranteeing a procedural balance that will put neither party at a disadvantage. In the judicial review of administrative action, the requirement of procedural equality can be approached from two angles, formal and material. Formal equality can be accomplished by treating both parties - both the administrative agency and the private party - in exactly the same manner. On the other hand, material equality requires that actual differences between the parties are accounted for without compromising the equilibrium of the procedure.

Finnish administrative law assumes that in administrative decision-making the administrative authority usually has de facto superiority of power compared to the private party. The executive's superior position is based on several factors, usually including the right to exercise unilateral public power, sophisticated expertise in legal and administrative issues, and broader access to government-held data and information. Of significance is also the administrative authority's general proficiency in conducting the decision-making procedure and participating in judicial procedures. Rarely, and perhaps only in the case of large companies or organisations, is the private party actually capable of matching the administration in all these areas.

As a consequence of these and similar factors, a considerable gap usually exists between the information and procedural skills of the private party and those of the administrative agency. Therefore, the procedural rules must be simple, transparent, easy to comply with and foreseeable. The court conducting the procedure must also actively ensure that the private party is not left at a disadvantage because of his or her inferior procedural skills or informational abilities. Similarly, the European Court of Human Rights has stressed that the requirement of equality of arms implies that "each party must be afforded a reasonable opportunity to present his case - including his evidence - under conditions that do not place him at a substantial disadvantage vis-à-vis his opponent".

\footnotetext{
${ }^{3}$ Mantovanelli v. France, ECHR (1997) § 33.

${ }^{4}$ See generally Kress v. France, ECHR (2001).

${ }^{5}$ Vilén v. Finland, ECHR (2009) § 21; Helle v. Finland, ECHR (1997) §§ 53-54.
} 
Against this backdrop, material equality as a supplement to formal equality is stressed in the Finnish legislation governing judicial proceedings in administrative courts. First, the administrative authority is not considered to have its own individual rights that it should defend as an adversary of the private party. Since public authority belongs to the public domain and is exercised in the general interest, an agency or official does not possess administrative authority. Second, although the agency is procedurally a party, it is nevertheless bound by the principles of legality, objectivity and impartiality as well as by the obligation to protect the general interest. Thus, its position as a procedural party neither relieves the agency of its official duties nor does it authorise partial action.

In a recent decision, the Supreme Administrative Court (KHO) emphasised that administrative authorities must act in a detached and impartial manner in judicial procedures based on the rule of law. Even when in the role of a procedural party, an administrative authority must take account of all the facts, regardless of whether they support or conflict with that authority's reasoning and conclusion. ${ }^{6}$ For instance, the authority must provide all the evidence at its disposal, even if it might compromise the authority's case. Furthermore, official statements submitted by the authority must be based on a neutral and objective evaluation.

\subsection{Definitions and characterizations}

\subsubsection{The dual role of the administrative courts vis-à-vis the executive}

To understand the function of judicial deference in the Finnish legal system, the dual role of administrative courts must be taken into account. First, administrative courts are considered to act as a constraint on the use of executive power, thereby upholding the rule of law and providing judicial protection for private actors. Second, the administrative courts are also understood to function as guarantees of the lawful implementation of legislation and legislative intent. In this sense, the role of the administrative courts is based on the idea that the court is not only the arbiter of a dispute between the executive and the private party but it also represents the general interest of society.

Judicial control of the executive is one of the cornerstones of the rule of law. It is conventionally understood to mean that the law acts as a constraint on both individual and public action. Therefore, government and those who govern must also be subjected to the law, and their actions must be independently reviewable.

Protection of individual basic rights, human rights and ordinary legal rights can be seen as the nucleus of the rule of law. In this respect, the right to challenge administrative decisions on legal grounds is a central guarantee of individual rights. This can also be understood as one of the main reasons for imposing independent judicial control and review on government and executive action. In this regard, the courts' chief role is negative and restrictive. The courts act as a constraint on the exercise of administrative power and as a provider of judicial relief in cases of an administrative encroachment on private rights as well as the abuse of executive power.

The law nevertheless also imposes obligations and sets down objectives to be achieved. It is the task of the executive to implement legislation and to realise rights, obligations and goals, and this provides courts with a constructive, even creative, role. Furthermore, since the actualisation of rights and obligations can be seen as a basic function of the executive within the framework created by the legislature, judicial review should also reinforce this task.

\footnotetext{
${ }^{6}$ KHO 2016:180.
} 
Consequently, the administrative court's role can also be characterised as that of a positive guarantor that legislative intent is carried through and that duties are observed.

\subsubsection{A characterisation of the concept of "deference" or "judicial deference"}

In common-law jurisdictions, judicial deference usually means that courts should primarily ensure legislative intent and its implementation by the executive. Therefore, the courts should also be deferential to administrative decision-making and accord it a varying degree of deference. $^{7}$ The deferential treatment of executive power may also imply that courts refrain from examining the discretion used by an administrative authority, with the exception of clearly unreasonable interpretations. For instance, in Chevron U.S.A., Inc. v. Natural Resources Defense Council, Inc., the US Supreme Court concluded that courts must "give effect to the unambiguously expressed intent of Congress". However, if the law in question is silent or ambiguous, courts must defer to any reasonable interpretation made by the administrative authority. ${ }^{8}$

With respect to the range and depth of review, one of the central questions concerns the degree of deference a court can or should concede to the executive authority. For instance, should the court be an active investigator or only a neutral or passive referee? Should the scope of review be limited to only the formal and procedural requirements of the exercise of administrative powers, or should the court have the authority also to scrutinise and judge the use of discretionary powers? In other words, should the court's default approach be to give a "green light" to administrative decision-making unless the decision is manifestly unlawful or based on grave unreasonableness, or should the court apply a more stringent and in-depth degree of scrutiny, amounting to a "red light" approach?"

Continental European jurisdictions apply varied standards of deference. For instance, in Finland, Sweden and France, the use of the executive's discretionary powers is subject to judicial review, even though the standards of review may vary. In Finland, the administrative courts have (and use) the power to investigate whether the authority in question has complied with general administrative principles (e.g. objectivity, equality, impartiality, proportionality, the protection of legitimate interests and the prohibition on abuse of power) when exercising its discretionary powers. Thus, even if the administrative authority has wide discretionary powers, it is within the courts' remit to evaluate how the use of those powers conforms to said administrative legal principles. Moreover, the review of legality also extends to the authorities' compliance with constitutional rights. ${ }^{10}$

As a legal concept, deference has failed to gain recognised status in Finnish legal doctrine. Nonetheless, in actual judicial practice, the administrative courts give certain consideration to the discretion of administrative decision makers. Such deference is moderated and limited by four significant considerations: 1) legality, 2) effective judicial protection, 3) fair trial and 4) the basic rights of the individual. Furthermore, deference to these four considerations tends to surpass deference to administrative discretion.

First, the rule of law, as such, signifies that consideration can only be given to an authority's interpretation to the extent that the applicable legislation allows administrative discretion.

\footnotetext{
${ }^{7}$ See in general Daly (2012).

${ }^{8}$ Chevron U.S.A. Inc. v. Natural Resources Defence Council Inc., 467 U.S. 837 (1984), 843-844.

9 The traffic-light theory was first introduced by Harlow \& Rawlings (1997) p 29-127.

${ }^{10}$ For a comparative analysis see e.g. Spiliotopoulos (2000).
} 
Moreover, the significant role of the principles of statutory administrative law imposes considerable constraint on the discretionary powers of any administrative decision maker. A strong tradition of legalism also plays a role in the emphasis on statutory law.

Second, the main duty of an administrative court is to provide effective judicial protection to the private party. The courts are first and foremost obliged to implement the constitutionally guaranteed right to an effective remedy. Any latitude to executive decision-making is secondary to this judicial function. Furthermore, the mind-set of administrative judges and the legal culture in administrative courts is very much based on the idea of effective judicial protection.

When conducting a judicial review, the administrative court must assess the decision making of an administrative agency or official in order to provide effective judicial protection. Both the scope and intensity of the court's review therefore become central issues in guaranteeing such protection.

Third, as a constitutional right, fair trial also sets limits to deference. Due process denotes the equal rights and duties of the parties involved, but it also imposes duties on the court. Since the rule of law also applies to courts, due process is a guarantee of both the procedural equality and fairness of the proceedings.

The fourth consideration is based on a reference to human rights and fundamental freedoms. In recent years, the administrative courts have adopted an approach to domestic legislation that favours human rights and basic rights at the expense of traditionally strict adherence to the letter of the law. This approach emphasises an authority's general duty, where possible, to interpret and apply statutes in a way that promotes basic and human rights. In a situation calling for interpretation, this principle thus requires authorities to choose the alternative best conducive to the implementation of human rights.

In a recent ruling, ${ }^{11}$ the Supreme Administrative Court based its argumentation on this approach by stressing that out of all the legally valid interpretations of the Act on Public Meetings, the administrative agency concerned must select the one that best promotes the realisation of basic rights. Therefore, the Police Department was considered to have acted ultra vires when it forbade a public artistic performance on the grounds of it being a potential affront to decency and public morality.

\section{Judicial Deference}

\subsection{The Scope of Deference}

An essential factor defining the relationship between courts and the executive is courts' ability to perform inclusive and wide-ranging judicial scrutiny. Since judicial review interferes with executive powers, at least whenever an administrative authority can be shown to have acted illegally, the latitude of that review is a measure of judicial power vis-á-vis executive power. ${ }^{12}$ Consequently, to the extent that courts can investigate the lawfulness of the administrative action, they can also affect the separation of powers between the judiciary and the executive. In this sense, the scope of judicial review also has constitutional dimensions. ${ }^{13}$

\footnotetext{
${ }^{11}$ KHO 2017:151.

${ }^{12}$ On the concept and scope of judicial review with respect to executive action, see Hertogh, Halliday, Simon, Arup (2004).

${ }^{13}$ On the constitutional implications in general, see e.g. Elliott (2001).
} 


\subsubsection{Judicial deference and the intensity of judicial review}

The intensity of judicial review is a crucial question when judicial review focuses on administrative action. Even if the formal reviewability of administrative acts is broad, there may be considerable case-by-case differences in the depth and intensity of the review and the active role of the courts in relation to executive authorities and their different kinds of action.

An ordinary administrative appeal is characterised as reformatory in nature. It thus allows the reviewing court to be relatively active at the investigative stage. The court is also required to conduct the procedure in an active manner and it is authorised to take a detailed stand on the contents of the case. For an ordinary administrative appeal, the degree of judicial scrutiny is also comprehensive. All issues of legality - including compliance with the principles of statutory administrative law - may be reviewed by the court, although it is not authorised to go beyond the grounds invoked in the appeal.

\subsubsection{Powers of the court}

The powers of the Finnish administrative courts are limited in the sense that a court may not substitute itself for the administrative authority which made the contested decision. There is an understandable reason for this reticence: the courts are judicial organs and they lack the power to make (original) administrative decisions. After annulling an administrative decision, the courts usually refer the case back to the administrative authority in question, while usually also indicating what amendments or improvements should be made.

An administrative court basically has the power to uphold or annul a contested decision. Moreover, in addition to affirming or annulling the decision subject to review, the court may also amend it. In particular, the courts are considered to have wide powers to amend contested decisions concerning the administrative application of environmental legislation or other regulatory decisions.

In environmental cases, for instance, the Supreme Administrative Court has frequently added new and tighter conditions to environmental permits. For example, in cases where the court finds that an environmental permit has been granted without taking sufficient account of the requirements of the applicable environmental laws, it may either annul the decision or uphold the permit but add stricter and more detailed conditions. ${ }^{14}$ Similar remedial powers may be used in other cases concerning the regulation of health standards or consumer protection, for example.

\subsection{Specific Types of Agency Action}

\subsubsection{Administrative decisions}

According to Section 5 of the AJPA, an appeal may be directed against any act or measure performed by an administrative authority whereby a matter has been resolved or dismissed. In this respect, no distinction is made between, for instance, administrative decisions and acts of state. Thus, administrative decisions by the Cabinet or the ministries, as well as those of central, regional and local authorities, may be subject to appeal, even if they were based on a very wide margin of discretion.

\subsubsection{Outsourcing}

\footnotetext{
${ }^{14}$ E.g. KHO 2017:167.
} 
The outsourcing of administrative functions to private actors has increased considerably during the last $10-15$ years. For instance, private companies or associations may perform administrative duties or produce public services. The right to challenge administrative decisions by appeal also extends to private organisations to the extent they are empowered to exercise public powers or perform public duties under specific provisions.

\subsubsection{Administrative Governance outside Judicial Review}

Due to the growth of the welfare state, the quantitative emphasis of administrative activity has shifted to providing social benefits and public services. Public administration has also become more involved in administrative networks and economic activities. Moreover, the administrative machinery has simultaneously grown and become more complicated, multilayered and integrated into the European administration.

The significance of the rule of law in public action has by no means diminished. However, new challenges to judicial review are posed by such developments as privatisation and decentralisation, regulatory reform, new forms of normative regulation and transformations in the mode and methods of administrative governance. Private law relationships are used when a public authority acts in the capacity of a private law subject, for instance as a landlord, tenant, buyer or employer. In that role, it may enter into private law relationships under the same conditions as any private subject. Judicial review by the administrative courts does not necessarily extend to these new modes and methods of administrative governance.

\section{Standards, approaches and grounds of review}

\subsection{Standard grounds of judicial review}

Since law governs the relationship between the executive and the private subject, legality and the rule of law are particularly central requirements in administrative decision-making. It is the administrative court's task both to judge the legality of the administrative decision and to provide judicial protection to the private party.

The administrative court needs to assess the action of the administrative agency or official concerned in order to provide judicial protection. Both the scope and intensity of the court's review therefore become central issues. The powers of the court are also of significance: how far and to what degree of detail can or should the court interfere with the powers of the executive by exercising its judicial powers in order to produce effective protection and redress?

Even though the standard and scope of judicial review may vary in different cases, it normally focuses only on whether the administration acted in a legal manner and within the powers defined by law and legal principles. Thus, reticence is expected of the courts in other issues that are not directly connected to the evaluation of legality. In particular, the scope of judicial review is considered limited in respect to policy issues and the actual exercise of executive power.

Administrative appeals are not, however, limited to specific grounds; in practice, the grounds for the appeal vary from case to case. Nevertheless, the decisions of executive authorities may only be appealed against on the grounds of legality. There is no exclusive list of what those grounds are, but in practice the appellant may successfully claim that the authority:

- has made a procedural error (e.g. there has been a conflict of interests),

- has exceeded its powers (e.g. acted without a legal basis) 
- has abused its discretionary powers by violating legal principles

- has otherwise acted in an unlawful manner.

The review of legality is thus also understood to extend to whether the exercise of discretionary powers has complied with general administrative law principles. Thus, even if an administrative authority has wide discretionary powers, the use of those powers can be reviewed by the courts.

Authorities' compliance with constitutional and human rights also comes within the scope of the review of legality. In practice this means that if, for instance, a ministry has dismissed an official for expressing certain opinions in public, the decision can also be appealed against on the basis that a constitutional right to free expression has been infringed. Here, the court must give precedence to that constitutional right and annul the ministerial decision if there are sufficient grounds.

\subsection{Principles of administrative law as grounds of review}

In addition to substantial legal regulation, a number of legal principles enjoy a prominent role in all administrative activity. The principles of administrative law provide a qualitative value basis for the interpretation and application of law by administrative authorities. They include the principles of objectivity, transparency, good governance and the prohibition of abuse of power.

While such principles were originally developed in administrative law doctrine and judicial practice, many have gradually been assigned a more binding legal role by elevating them to constitutional entitlements or by enshrining them in ordinary laws. In this way, the principles have become part of the law that the courts must uphold. The general principles of administrative law have, moreover, gradually acquired their binding quality in the case law of the Supreme Administrative Court.

At present, there are five statutory legal principles that must be observed in all executive activity and administrative decision making. These are the principles of equality, impartiality, proportionality, prohibition of the abuse of power, and the protection of legitimate interests. These principles have also been codified in the Administrative Procedure Act. Section 6 states that "[a]n authority shall treat the customers of the administration on an equal basis and exercise its competence only for purposes that are acceptable under the law. The acts of the authority shall be impartial and proportionate to their objective. They shall protect legitimate expectations as based on the legal system."

These statutory principles mainly function as guidelines for and constraints on using discretionary administrative powers. The principles may be relied on by private individuals in administrative procedures, and they can also be asserted in judicial proceedings related to administrative decisions. Thus, administrative decisions taken in breach of one of these principles may be annulled or revoked by administrative courts.

Any procedure or decision conflicting with these general administrative principles can be challenged as a misuse of power, especially in connection with an appeal. In judicial review, the misuse of executive power has been established as independent legal grounds for annulling or revoking an administrative decision. The observance of these principles can also be deemed to belong to the official duties of public servants. The establishment of legal accountability for a public act is thus possible as a consequence of a procedure that violates these principles.

\subsection{Constitutional grounds for review}


The Constitution obliges administrative courts to accord primacy to constitutional provisions should the application of a law be in evident conflict with the Constitution (Sec. 106, Constitution Act). ${ }^{15}$ In actual practice, this duty empowers the administrative courts to consider the constitutionality of a legislative norm in an individual case. Thus, while legislative acts cannot, as such, be challenged in an administrative court and they cannot be declared invalid, no procedural rule prevents a legislative norm from being disputed in connection with an appeal directed against an administrative decision taken pursuant to such a norm.

If an administrative court finds that a legislative provision applied by the authority concerned is in evident conflict with the Constitution, the court is obliged to disapply that provision and apply the constitutional provision in its stead. In this manner, the administrative courts have the power - and the obligation - also to examine the constitutionality of the legislative norms applied by the administration in a specific case. Nevertheless, in recent discussions, the justifications for the evidence-test have been criticised and calls have been made for its removal from the Constitution Act.

There is no similar limitation on the powers of the courts with respect to delegated legislation and different kinds of administrative norms and instructions. Instead, in considering an administrative appeal, the courts are bound by Section 107 of the Constitution Act, which puts them under an express obligation to disapply government decrees and similar norms of inferior rank to the extent that they conflict with the Constitution or an Act of Parliament. ${ }^{16}$ This constitutional provision can be seen as creating the judicial power to examine the constitutionality and legality of delegated legislation when considering an appeal against an individual decision.

\subsection{The effectiveness of judicial review}

The effectiveness of judicial powers can be measured in a number of dimensions. One can assess, for instance, the remedial, reformatory, constructive, compensatory, constitutional and interim powers of a court.

Remedial powers constitute the main foundations of any judicial remedy. In short, the administrative courts have the power to uphold or annul a contested administrative decision. The courts may also refer the case back to the administrative authority for reconsideration.

Reformatory powers refer to the administrative courts' power to substantially amend or otherwise modify the administrative decision subject to review. For instance, in cases concerning the application of environmental legislation or other regulatory decisions, the courts have the power to amend a positive decision by supplementing it with more stringent conditions or limitations.

Constructive powers refer generally to the administrative courts' power to impose new obligations, restrictions or positive objectives on the administrative authority. Such powers are situated squarely on the problematic boundary between the judiciary and the executive. In principle, the courts cannot assume executive functions, but, on the other hand, they must provide effective judicial protection. Thus, how far does the objective of remedial effectiveness

\footnotetext{
15 Section 106: "If in a matter being tried by a court, the application of an Act of Parliament would be in manifest conflict with the Constitution, the court shall give primacy to the provision in the Constitution."

${ }^{16}$ Section 107: If a provision in a Decree or another statute of a lower level than an Act is in conflict with the Constitution or another Act, it shall not be applied by a court of law or by any other public authority.
} 
empower the courts to extend their jurisdiction into the realm of the executive in a constructive manner? Established doctrine and case law tend to favour considerable reticence in this respect. However, a more practical and extensive interpretation is possible if more emphasis is placed on the corrective outcome of the review.

Compensatory powers refer to the courts' power to hear restitution claims arising from a violation of rights or duties under administrative law and to award damages for the harm caused by the activity (or failure to act) of an administrative agency. In Finland, the compensatory powers of the administrative courts are limited, since in most cases only ordinary civil courts can award damages against the administration. In principle, the powers of administrative courts could just as well include compensatory powers, since there are no fundamental reasons or statutory constraints to limit their remedial powers in this respect.

Constitutional powers define the boundary between the judiciary and the legislature. A critical yardstick is whether the courts are empowered to declare a legal provision null and void if it violates the Constitution. The administrative courts lack the power to invalidate an act of parliament even if they find it in conflict with constitutional provisions. Similarly, the administrative courts are not empowered to declare a legal provision null and void if it violates the constitution. Nevertheless, if the conflict between a legal norm and the Constitution is clear, it may be the courts' duty to refuse to apply the disputed legal provision and, instead, give precedence to the Constitution in a concrete case.

Interim powers refer to the courts' power to issue administrative agencies with injunctions and to stay the execution of an administrative decision. Since the duration of a judicial procedure can vary and proceedings can be delayed, interim powers may offer significant, albeit provisional, judicial protection.

\section{Dimensions of Deference}

\subsection{The Role of Information and the Investigation Principle}

The courts have the ultimate responsibility to guarantee procedural fairness. The administrative courts are under a general obligation to actively conduct the proceedings and obtain evidence and factual information, also on their own initiative. In this sense, the appeals procedure is characterised by the investigation principle, according to which the court is responsible for comprehensively scrutinising the contested decision. As a part of this responsibility, the court is required to review all evidence available and examine the facts and considerations on which the decision is based. Furthermore, the court must "on its own initiative obtain evidence in so far as the impartiality and fairness of the procedure and the nature of the case so require" (Sec. 33(2), AJPA).

Since the administrative courts may use their own initiative to acquire the necessary supplementary information, they are empowered to conduct their own investigation into the substantive issues of the case and collect evidence. For this purpose and where necessary, the court must inform the party or administrative authority of the additional evidence to be presented. The court may also take account of evidence not presented by the parties, provided, of course, that the parties have been provided an opportunity to comment on it.

Although the administrative court has the power to examine of its own motion the facts of the case before it, fairness and impartiality of the procedure requires that the court may not substitute itself for the administrative authority. As a procedural party in the case it is therefore the authority's responsibility to provide all the evidence necessary to enable that court to 
determine whether it acted within the limits of its legal obligations. Should the authority fail to provide such information or justification for its decision, the court is required to draw all inferences which result from such failure.

\subsection{Judicial Construction}

The rule of law, and especially the requirement and principle of conformity to law, can be problematic in the administration of the modern state. On one hand, the law cannot be 'strictly' observed, as the Constitution requires, if the applicable provisions are broad and if they entitle an authority to use discretionary power. In such situations, the principles of administrative law have a central role in supplementing the formal duty to adhere to legal norms.

\subsection{Proportionality and other legal principles}

Since any administrative decision conflicting with the general administrative principles can be challenged on the grounds of misuse of power (see under II.3.1), compliance with the principle of proportionality can also be reviewed by the administrative courts.

\section{Activism or Restraint}

In addition to the scope of judicial review, another measure of the character of the courtexecutive relationship is the degree of judicial activism. An active court is required to conduct the proceedings in a dynamic manner and investigate on its own initiative; moreover, the court is also empowered to take a detailed stand on the contents of the case. In this manner, the court is thought to be able to promote equilibrium in the inherently unbalanced relationship between the executive and private parties.

In Finland, as in several other continental European jurisdictions with separate administrative courts, procedural law tends to attribute an active role to the courts. ${ }^{17}$ As previously mentioned, the administrative courts are under a general obligation to actively conduct proceedings. The appeals procedure is characterised by an investigative principle, according to which the court is responsible for comprehensively scrutinising the contested decision. Although the burden of proof lies with the parties involved, the court may also obtain evidence and factual information on its own initiative if this is deemed necessary to supplement the evidence supplied by the parties and to guarantee the fairness of the procedure.

However, a more restrained procedural model is applied especially in tax law cases and administrative litigation as a special procedure concerning administrative disputes. Both procedures rely more clearly on the activity of the parties involved, who are expected to obtain and present the substantive evidence. Since the parties share the burden of proof, the administrative court rarely acts on its own initiative. In these procedures, the court is, in fact expected to base its decision solely on the evidence presented by the parties, the executive party and the private party.

\section{Limits of Judicial Review}

\subsection{Policy Issues}

\footnotetext{
${ }^{17}$ Galera (2010).
} 
Judicial review focuses on whether the administration has acted in a legal manner and within the powers defined by law, whereas administrative policies are considered to be the exclusive domain of the executive. Therefore, investigation of the advisability and expediency of an administrative decision falls outside the jurisdiction of the administrative courts, and policy issues should be excluded from judicial review - provided of course that the authority concerned has used its discretion within the limits defined in law. However, the line between administrative policy and discretion is difficult to draw, and the limits of judicial review in this area are, to a certain extent, open to interpretation.

For instance, if an administrative authority were to consider a choice between several lawful alternatives, the decision would depend primarily on a consideration of expediency, i.e. a question of policy. The administrative courts are considered to lack the power to choose between various lawful alternatives and thus impose their will on the executive. Indeed, in a recent case, the Supreme Administrative court affirmed this approach. ${ }^{18}$ The case concerned the Firearms Act (1998), according to which, an acquisition permit may be granted, among others, for target shooting or practice if the firearm is not unnecessarily powerful for the purpose stated by the applicant. The Police Department has discretion in granting an acquisition permit, and no one has a universal right to obtain such a permit. Consequently, the Supreme Administrative Court ruled that the rejection of a permit application was within the statutory limits of the Police Department's discretionary powers.

\subsection{Separation of Powers}

A further limit to judicial power is based on constitutional principles, more precisely on the separation of powers doctrine. According to that doctrine, the actual adoption of an administrative decision belongs exclusively to the sphere of executive power. Because the courts are judicial organs, they lack the power to exercise executive power and to make original administrative decisions. Consequently, a court should not substitute itself for the administrative authority which has made the contested decision. Nevertheless, this limitation can only be indicative, since the courts are commonly considered to have the power to amend administrative decisions, at least under some circumstances.

\subsection{Constitutional Review}

Finland lacks a specific constitutional court, but the courts and other authorities are required to interpret legislation in such a way as to comply with the Constitution and respect human rights. In deciding a case, the courts must give primacy to the Constitution. If an applicable provision in a law is in apparent conflict with the Constitution, the court must disapply that provision and instead apply the Constitution. However, the judiciary lacks the power to declare a law invalid and unconstitutional.

The administrative courts are only constitutionally empowered to perform limited judicial review of legislative acts. This power is relatively new, since it was only introduced in the Constitution Act of 2000. If a court finds that a provision in an Act of Parliament is in manifest conflict with the Constitution, the court shall then disapply that provision and give primacy to the Constitution.

\subsection{Administrative Inaction}

There remains a problematic gap in the reviewability of executive action. If an authority remains passive, delays the matter, or completely fails to act, no appeal is available against

\footnotetext{
${ }^{18}$ KHO 2017:130.
} 
such conduct or omission. Unless there is a specific provision making inaction reviewable, the only, albeit fairly ineffective, remedy is an informal administrative complaint which can be made to a superior authority or and the Ombudsman (the Parliamentary Ombudsman or the Chancellor of Justice).

\subsection{Local Self-government}

The scope of review generally depends also on the nature of the appeal. The degree of judicial scrutiny is comprehensive in an ordinary administrative appeal; by contrast, it is more limited and passive in cases concerning a municipal appeal. In both cases, the court nevertheless has the power either to affirm or overrule the decision challenged by appeal.

Ordinary administrative appeal is characterised as a reformatory type of appeal, which allows the court to be more active at the investigative stage and which also gives it wider powers in passing judgment. By contrast, municipal appeals concern cassation, which means that the appellate court is required to conduct the procedure in a more passive and adversarial manner, and its powers are more limited. Furthermore, proceedings are conducted in a more active manner in ordinary administrative appeals, where the court is empowered to take a more detailed stand on the contents of the case.

\section{Concluding Remarks}

The role of judicial deference varies between different legal systems due to context and traditions, juridical cultures, divergent perceptions of the proper functions of the courts, and the value accorded to judicial protection. The Finnish legal system shows only limited judicial deference to administrative discretion. Instead, more value is generally accorded to effective judicial protection and other related factors, such as adequate access to a court, guarantees of procedural fairness, the sufficiently broad scope of judicial review, effective remedies and a relatively active role for the administrative courts.

However, a more detailed analysis might reveal distinct and fruitful tensions in the relationship between the courts and the executive with respect to their different functions in exercising public power. The courts exercise judicial power and play a central role in offering legal protection to individuals affected by administrative decision-making. The basic function of the executive, on the other hand, is to exercise administrative power in order to realise rights and obligations within the framework defined by the legislature.

The tension primarily arises from the fact that judicial review can constrain the exercise of executive power because of its emphasis on adherence to the law and legal principles. Nevertheless, judicial review can also support administrative activity, since the courts and the executive share the function of guaranteeing legality and the rule of law, both in individual cases and in the implementation of legislative intent. ${ }^{19}$

Well-functioning judicial review and effective remedies are necessary guarantees of legal protection for individuals subject to executive power. They are also needed to ensure that administrative action complies with the law. Even in an ideal situation where laws are correctly observed and implemented by the administration in a proactive and practical manner, the possibility of judicial review would still be required for preventive reasons.

\footnotetext{
${ }^{19}$ For more detail, see Mäenpää (2017).
} 


\section{References}

Daly, Paul (2012) A theory of deference in administrative law. Cambridge.

Elliott, Mark (2001) The Constitutional Foundations of Judicial Review. Oxford.

Galera, S (ed) (2010) Judicial review: a comparative analysis inside the European legal system. Strasbourg.

Harlow, Carol, Rawlings, Richard (1997) Law and Administration. London. (1 ${ }^{\text {st }}$ ed. 1984).

Hertogh, Marc, Halliday, Simon, Arup, Chris (2004) Judicial Review and Bureaucratic Impact: International and Interdisciplinary Perspectives. Cambridge.

Letto-Vanamo, P, Tamm, D, Gram Mortensen, B (eds) (2019) Nordic Law in European Context. Springer.

Mäenpää, Olli 2017 Judiciary v. Executive: Judicial Review and the Exercise of Executive Power. Juridiska Föreningens Tidskrift 2-4/2017, p 242-255.

Nuotio, K \& al. (eds) (2012) Introduction to Finnish Law and Legal Culture. Helsinki.

Spiliotopoulos, E (ed) (2000) Towards a Unified Protection of Citizens in Europe (?). London. 